patriarchy, women's access to a regular wage has meant more control over their lives and more autonomy in relation to men in households, thus providing support for the 'integrationist' thesis. But on the job front she remains highly critical of this approach, arguing that 'the integration perspective's neglect of the systemic foundations making public patriarchy so tenacious leads to a distorted picture of the probable consequences of women's rising labor-force participation' (1994: 224).

Despite the fact that neither study treads particularly new theoretical ground, both are well researched and provide excellent empirical insights into the complexity and dynamics of different dimensions of gender relations.

Annie Phizacklea

\title{
Abortion in the New Europe: A Comparative Handbook
}

\section{Bill Rolston and Anna Eggert (eds)}

Greenwood Press: Westport, Connecticut, 1994

ISBN 0313287236 £67.50 Hbk

One of the first pieces of state socialist legislation to be dismantled in many of the countries of the former Soviet bloc was legal abortion. It was an extraordinary paradoxical spectacle - the politicians of the new democracies asserting that the exigencies of the transition to market economies must take top priority over the frivolities of women's rights. Somehow, however, they found time to put this attack on women's reproductive rights at the top of the agenda - in Hungary, Slovakia, and Poland. It was a grim object lesson in the dangers of complacency about the security of laws protecting abortion.

For many feminists in Britain and much of Europe, abortion is yesterday's issue. Despite the shortcomings in the 1967 Act, which gives women the right only to plead with two doctors for abortion, it is incredibly hard to get up a political head of steam to extend or change the law, and almost as hard to impress on the public that the anti-abortion lobby has not relinquished its campaign to erode the law by backdoor stratagems, court cases, seemingly minor changes to regulations, and so on. I know this from my own experience, having just completed a book on the international politics of abortion and seen the glaze come across feminists' 
eyes when they hear the word. It's old hat: the politics of reproductive technology is what lights fires in the 1990s.

Not so for Bill Rolston and Anna Eggert, who have patiently assembled this commentary on abortion laws in Europe. They live and work in a context where abortion remains as contentious as ever - Northern Ireland. No one can be complacent there, since the final sentence of the 1967 Abortion Act states, 'This Act does not extend to Northern Ireland', and women of the province have to 'take the boat' to Liverpool or London in exactly the same way as their sisters from the South. Rolston and Eggert are both founder members of Northern Ireland's Abortion Law Reform Association, and also work in the faculty of health and social sciences at the University of Ulster.

Their book is divided into chapters - one for almost every country in Europe. The format is consistent and enables the reader easily to compare the history of the national abortion law, the current law, practice, and the politics of abortion. Each contributor also gazes into the crystal ball to assay what the future may hold. It is a fast changing scene - several countries, such as Hungary and Poland, contain a final update section. Already, by the time of writing this review, the scene has changed again. With arch opponent of abortion (and father of eight) Lech Walesa thrown out by the Polish electorate in November 1995, the knife-edge balance of Polish abortion politics has shifted yet again and the stage is poised for a fresh round of attempts to restore legal abortion.

Despite the consistent format, the book's coverage is patchy. The quality of the contributions is rather uneven - an inevitable hazard in a book in which you have to rely on finding a contact and hoping that he/she will provide a bone-clear, well-written analysis. For some countries there is no coverage at all, which is particularly regrettable in the case of Greece and Italy. In Greece, there is a very high abortion rate and low use of contraception: doctors, happy to receive fat fees for abortions, do little to promote contraception or to pressure the government towards investment in health education. In Italy - 'so close to the Vatican, so far from God' goes the quip - abortion is openly practised and the law turns a blind eye.

It is all too easy to think that access to abortion resides in what the law says - if it is legal, women can get it, if it is illegal, women will get maimed and die and racketeering will flourish. It ain't necessarily so. In The Netherlands, for example, abortion was not legal until the early 1980s, but for more than a decade before that, abortion had been available in pristine, no-profit clinics, and no one had been jailed or martyred for the cause. What this book shows clearly is that the law is only half 
the story; and that, even though law which recognizes abortion is always to be preferred to having it outside the law, getting legal abortion on to the statute books does not put an end to the politics. There will always be a political fight threatening abortion and women will have to maintain constant watchfulness to protect this essential element of women's reproductive freedom.

This book provides an invaluable resource - a benchmark of abortion laws and policies in a context of turmoil and controversy. For lawyers and social scientists alike, Rolston and Eggert have compiled an excellent book of reference.

Janet Hadley

\section{Women in the Housing Service}

\section{Marion Brion}

Routledge: London, 1995

ISBN $0415080940, £ 45.00 \mathrm{Hbk}$

I can remember Miss Samuel pleading, with tears in her eyes 'If you let men in, they'll take over all the best jobs, they'll be Directors of Housing, you'll be the rent collectors'.

(Former member of the Society for Women Housing Managers)

Women in the Housing Service is a rare example of an account of the housing movement which is actually interesting and enjoyable to read. Brion attempts to cover eighty years of women's employment in housing and provides the reader with much more than a dry historical account of British housing policy and practice. Her book brings to life the era between the time when Octavia Hill first identified women's role in housing management and the present day. It identifies factors which influenced women's employment in housing at the various stages, records the contribution of the Society of Housing Managers to this, and examines the implications for women working in housing today and in the future.

The book traces the gradual development of organized groups of women housing managers after the death of Octavia Hill in 1912 and looks critically at the inception of the Association of Women Housing Managers in 1916. The work of the Association is considered with reference to its role in training and supporting women. There is a discussion of the rapid expansion of state involvement in housing provision between 1932 and 1939 as well as the increase in opposition to women's employment. 